Sensors 2008, 8, 1222-1236

sensors

ISSN 1424-8220

(C) 2008 by MDPI

www.mdpi.org/sensors

Full Research Paper

\title{
Application of GeoWEPP for Determining Sediment Yield and Runoff in the Orcan Creek Watershed in Kahramanmaras, Turkey ${ }^{\dagger}$
}

\author{
Alaaddin Yüksel ${ }^{1, *}$, Abdullah E. Akay ${ }^{1}$, Recep Gundogan ${ }^{2}$, Mahmut Reis ${ }^{1}$ and \\ Muzaffer Cetiner ${ }^{1}$
}

1 Kahramanmaras Sutcu Imam University, Faculty of Forestry, Department of Forest Engineering, 46060, Kahramanmaras, Turkey. E-mail: ayuksel@ksu.edu.tr, akay@ksu.edu.tr

2 Kahramanmaras Sutcu Imam University, Faculty of Agriculture, Department of Soil Science, 46060, Kahramanmaras, Turkey. E-mail: rgundogan@ksu.edu.tr

* Author to whom correspondence should be addressed; E-mail: ayuksel@ksu.edu.tr , Tel: +90 344 2237666, Fax: +90 3442217244.

$\dagger$ This work was partially presented in the International Congress of River Basin Management, Antalya, Turkey, March 2007 [7].

Received: 25 January 2008 / Accepted: 13 February 2008 / Published: 22 February 2008

\begin{abstract}
The geo-spatial interface of the WEPP model called GeoWEPP uses digital georeferenced information integrated with the most common GIS tools to predict sediment yield and runoff. The model determines where and when the sediment yield and runoff occurs and locates possible deposition places. In this study, the sediment yield and runoff from Orcan Creek watershed in Kahramanmaras region was estimated by using GeoWEPP model. To investigate the performance of the model, the sediment yield and runoff results from the GeoWEPP model were compared with the observed monthly data collected from the sample watershed. The average Root Mean Square Errors (RMSE) between observed and predicted average annual sediment yield and runoff were 2.96 and 8.43 , respectively. The index of agreement was 0.98 and 0.99 for sediment yield and runoff, respectively, which indicated that the model predictions provided good results.
\end{abstract}

Keywords: GeoWEPP, Sediment Yield, Runoff, GIS, Kahramanmaras 


\section{Introduction}

In Turkey, topsoil faces moderate (20\%), severe (36\%), and very severe $(22 \%)$ soil erosion incidents due to excessive amount of runoff by water in the mountainous regions and topsoil removal by wind in steppes [1]. Soil erosion and unimpeded runoff alter the stream flow regime and generate considerable amount of sediment yield, which leads to dramatic environmental impacts on water quality and aquatic habitat $[2,3]$. Therefore, accurate and quick prediction of sediment yield and runoff in the watersheds is crucial in terms of planning and applying necessary soil conservation techniques in Turkey [4].

There have been several models developed to estimate sediment yield and runoff such as RUSLE, EPIC, ANSWERS, CORINE, ICONA and WEPP. In RUSLE (Revised Universal Soil Loss Equation), the annual soil loss per unit are is estimated using an empirical equation developed based on various erosion factors considering all climates, soil types, topography, and land types [5, 6, 7]. The EPIC (Erosion Productivity Impact Calculator) model assesses the effect of soil erosion on soil productivity to determine the effect of management strategies on soil and water resources. EPIC has some advanced simulation features including weather, nutrient cycling, plant growth, soil temperature, and plant environment control [7].

ANSWER (Areal Nonpoint Source Watershed Environment Response Simulation), one of the first true distributed parameter hydrologic models, was developed to evaluate the effects of the best management practices on sediment yield and runoff from agricultural watersheds [8]. The upgraded version of this model was developed to improve nutrient submodels and to allow a user to perform long term continuous simulations [7, 9]. CORINE (COoRdination of INformation on the Environment) model was developed by European Community based on Universal Soil Loss Equation (USLE) [10], a well-known methodology in soil erosion assessment studies [11]. The CORINE has the advantage of providing erosion prediction for the entire research area. Mapping soil erosion risk with CORINE methodology is very important for the integration of future scientific studies between European Community and Turkey $[11,12]$. As a sequel to CORINE, they developed ICONA model (Institute for the COnservation of the NAture), which works based on a large amount of geological data [12]. ICONA is useful to predict soil loss for large areas but it cannot consider the effects of climatic data [7].

The WEPP, The Water Erosion Prediction Project, was developed to estimate sediment yield and runoff based on specific erosion factors including soil type, climate conditions, ground cover percentage, and topographic condition [13]. The WEPP model calculates sediment yield, runoff, infiltration, and erosion and deposition rates for every day and for multiple time periods (i.e. monthly or yearly). Since WEPP is process-based model, it requires great amount of input data to evaluate erosion and sediment yield potentials [14]. In order to simplify the WEPP applications, FS WEPP (Forest Service WEPP) was developed as a set of internet-base interfaces, which assists a user to quickly predict sediment yield and runoff from forest roads, forest lands, agricultural areas, rangelands, and wild-fire [7, 15].

GeoWEPP, a geo-spatial erosion prediction model, was developed to integrate the advanced features of GIS (Geographical Information System) within the WEPP v2006.5 such as processing digital data sources and generating digital outputs [7, 16, 17]. GeoWEPP overcomes the limitation of the WEPP, which is that the user must manually generate necessary input data. The current version of GeoWEPP allows a user to process digital data such as Digital Elevation Model (DEM), ortho-photos, soil surveys, land use maps, and precision farming data. Besides, required input data including slope, 
land cover types, soil map, land use types, and climate are integrated into spatial database of the WEPP and necessary outputs are produced by using GIS functions of GeoWEPP.

In this study, GeoWEPP (WEPP v2006.5) was used to estimate the sediment yield and runoff in Orcan Creek watershed of Kahramanmaras. The sediment yield and runoff results from the GeoWEPP model were compared with the observed monthly data collected from the sample watershed to evaluate the performance of the model.

\section{Material and Method}

\subsection{GeoWEPP}

GeoWEPP was developed as a collaborative project conducted by the Agriculture Research Service, Purdue University, and the USDA National Soil Erosion Research Laboratory [17]. To predict sediment yield and runoff at watershed scale, GeoWEPP integrates WEPP model and TOPAZ (TOpography PArameteriZation) software within the ArcView 3.2 (ArcView 2000) [17] (Figure 1). In GeoWEPP, necessary input files (land cover, land use, slope, climate, soil, and management) are generated within WEPP and topographic data are parameterized by using TOPAZ based on DEMs [18]. Finally, watershed outputs are produced by using GIS functions in ArcView [7].

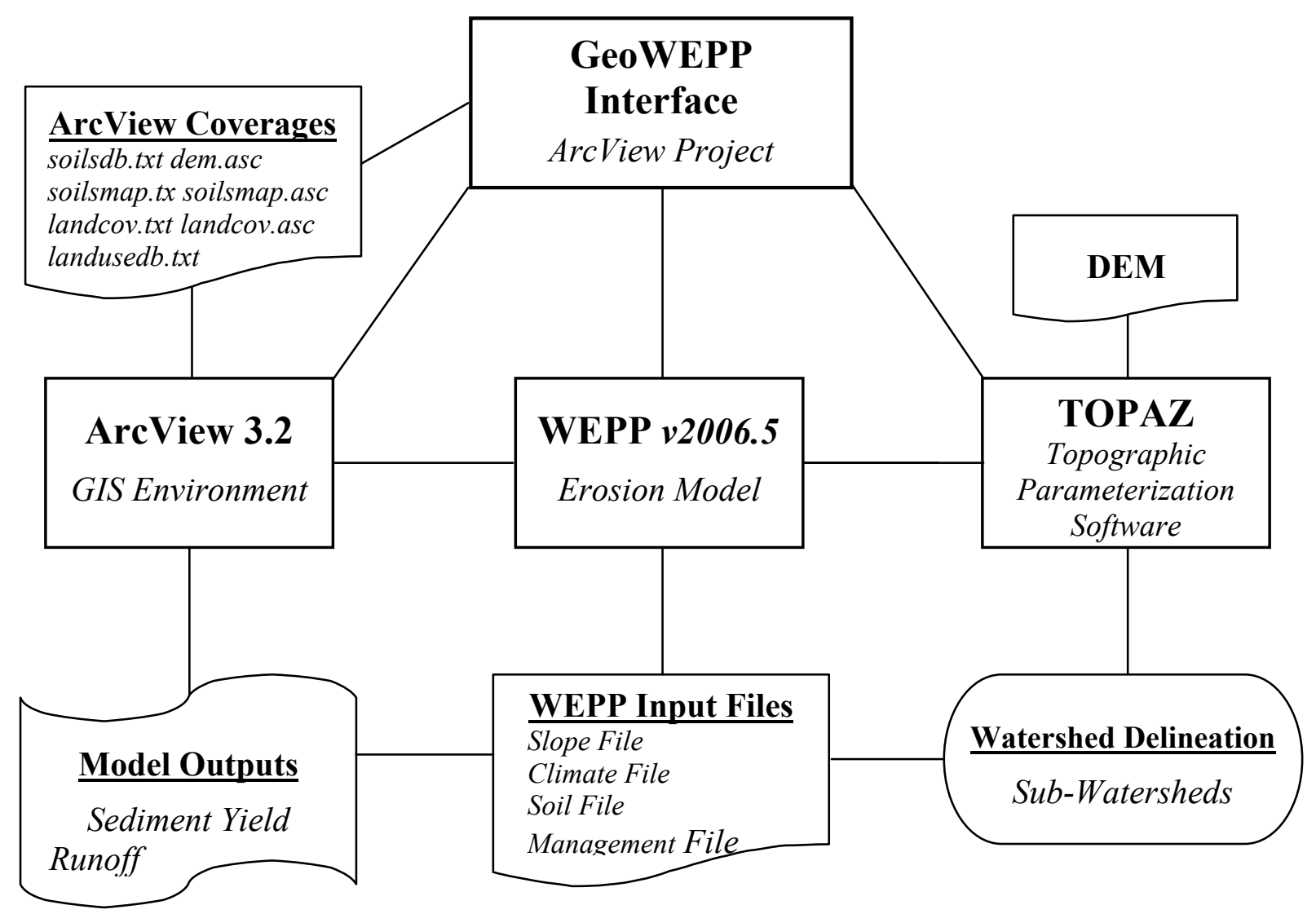

Figure 1. Logic flowchart of the GeoWEPP. 


\subsubsection{TOPAZ}

In GeoWEPP, hillslope profiles are generated by utilizing TOPAZ, which parameterizes topographic data based on DEMs. TOPAZ determines the channel network based on the steepest down slope path, considering 8 adjacent cells of each raster cell (pixel) [19]. The channel network can be adjusted by changing values of Mean Source Channel Length (MSCL) and Critical Source Area (CSA). The MSCL defines the shortest channel length and the CSA is the minimum drainage area [7, 19]. After defining the channel network, TOPAZ generates the sub-watersheds which represent the watershed (Figure 2).

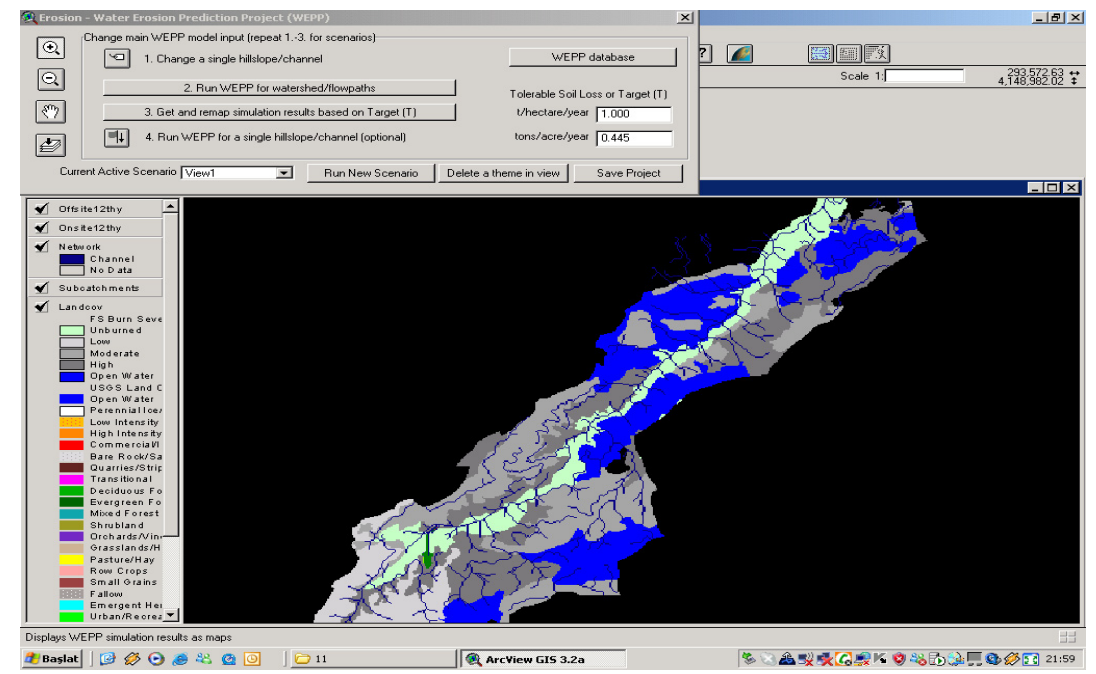

Figure 2. The flow accumulation for sub-watersheds by using TOPAZ.

\subsubsection{ArcView}

The GeoWEPP model has a feature of being run in ArcView. The watershed outputs are generated as grid layers representing soil loss as a percentage of the tolerable soil loss (TSL). In the grid layers, areas that generate soil loss values greater than or less than the TSL are highlighted. The runoff and sediment yield data for each pixel can be produced in text files or in grid outputs. Text files indicate average annual rainfall and number of storms, total runoff, soil loss, and sediment yield for each subwatersheds and for the entire watershed [7].

\subsubsection{WEPP Input Files}

WEPP model requires four input files including slope, climate, soil, and management files to describe hillslope geometry, meteorological characteristics, soil properties, and ground cover, respectively.

\section{Slope File}

The slope file is generated based on necessary hillslope parameters such as slope gradient, shape, width, and orientation along its length. GeoWEPP utilizes TOPAZ to produce sub-watershed profiles based on DEM data (Figure 3). In this study, sub-watersheds and channels in the study area were derived from $30 \mathrm{~m}$ DEMs, generated by using TOPAZ based on the 1/25000 scale topographic maps. 


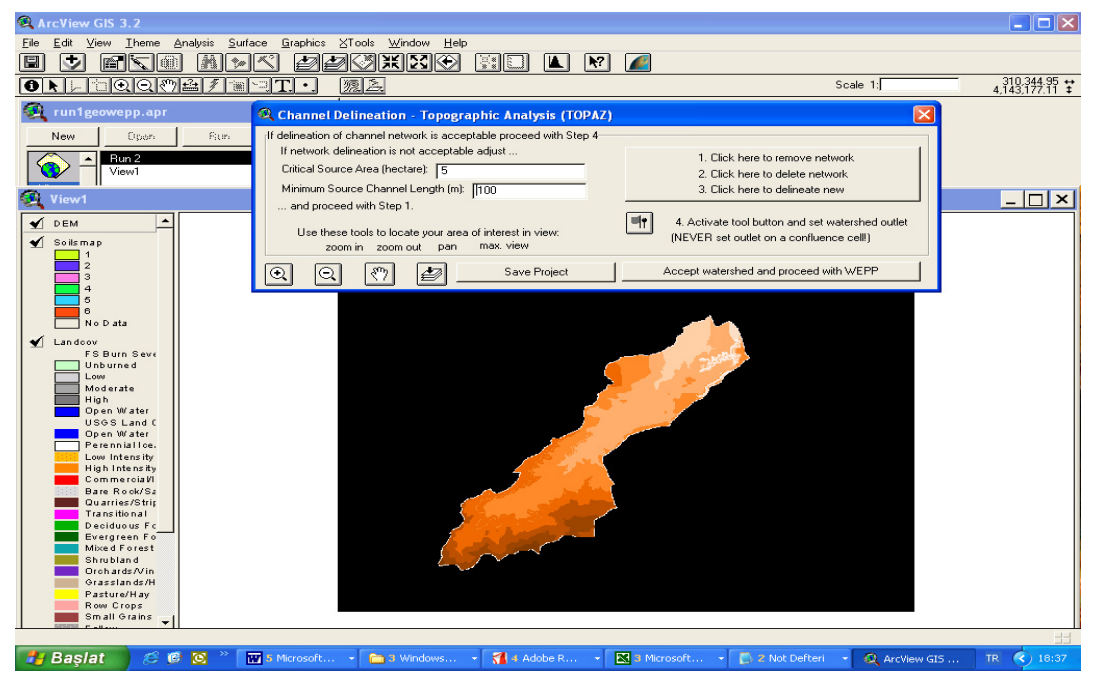

Figure 3. DEM image generated in ArcView.

\section{Climate File}

To generate climate file with daily values of precipitation, temperature, solar radiation, and wind speed obtained from the weather stations, the WEPP model uses CLIGEN (Climate Generator), which is a stochastic weather generation model [20]. For a specific location and length of time, the "Rock: Clime" application in FS WEPP is used to determine spatial climate variability in mountain regions [7, 15, 20]. To generate climate data, "Rock: Clime" can access database of PRISM (Parameter-elevation Regressions on Independent Slopes Model), which estimates precipitation and temperature based on orographic effects [22]. In "Rock: Clime", the inputs of monthly average precipitation and temperature values can be adjusted [23]. Since meteorological database in Turkey is not generated in the data format of CLIGEN model, climate parameters for the study area were first obtained from the weather station in the city of Kahramanmaras, tramsformed into the format called PAR file, and then generated in the WEPP as a climate file of CLIGEN (Figure 4). The climate parameters include maximum and minimum air temperature, relative humidity, precipitation, solar radiation, and wind speed.

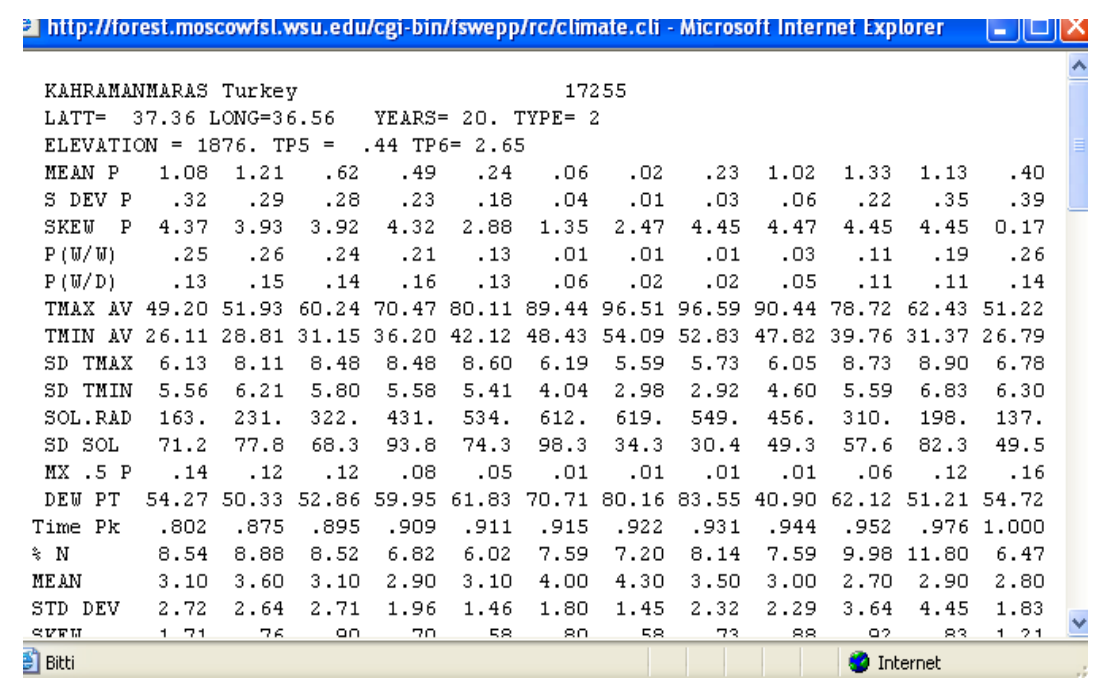

Figure 4. Climate file generated based on a PAR file. 


\section{Soil File}

Accurate representation of soil property values in WEPP is essential for estimating sediment yield and runoff. In WEPP, critical parameters in the soil file are soil texture, albedo, saturation level, hydraulic conductivity, rill erodibility and interrill erodibility, and critical shear. These parameters are obtained from data collection or calculated by the WEPP model. In this study, soil parameters were measured based on soil samples collected from randomly selected $1 \mathrm{~m}^{2}$ plots (i.e. 80 plots) located in the study area. After collecting soil samples from the selected sub-watersheds in study area and analyzing them in the soil laboratory, some of the soil properties including soil texture, albedo, saturation level, soil depth, sand-clay-organic matter ratios, cation exchange capacity, and rockness should be entered into soil input file. The values of the other properties such as rill and interrill erodibility, critical shear, and hydraulic conductivity can be calculated by WEPP model. The GreenAmpt effective hydraulic conductivity equation is used to estimate hydraulic conductivity based on rainfall amount, surface cover, and runoff [7, 24, 25]. Rill and Interrill erodibility values can be determined depending on the sediment delivery equation in WEPP v2006.5.

To run GeoWEPP, first, the soil map layer (soilsmap.asc) is generated based on soil input file in ArcView environment (Figure 5a). Then, soil text file (soilsmap.txt) (Figure 5b) is developed according to associated land cover types such as shrub, dry forest, wet agriculture, bare soil (rangeland), dry agriculture, and forest. The soil text file is used by GeoWEPP and WEPP/TOPAZ Translator (Figure 5c) to determine the description that corresponds with the soil map layer in GeoWEPP. In the text file, special codes (NumberKeys) are assigned to represent the raster cell values in the soil map layer [18]. The "NumberKey" values are to be followed by the description to describe soil types. In order to run GeoWEPP and WEPP/TOPAZ, soil text file is used as a bridge between soil map layer and WEPP/TOPAZ Translator (Figure 5).

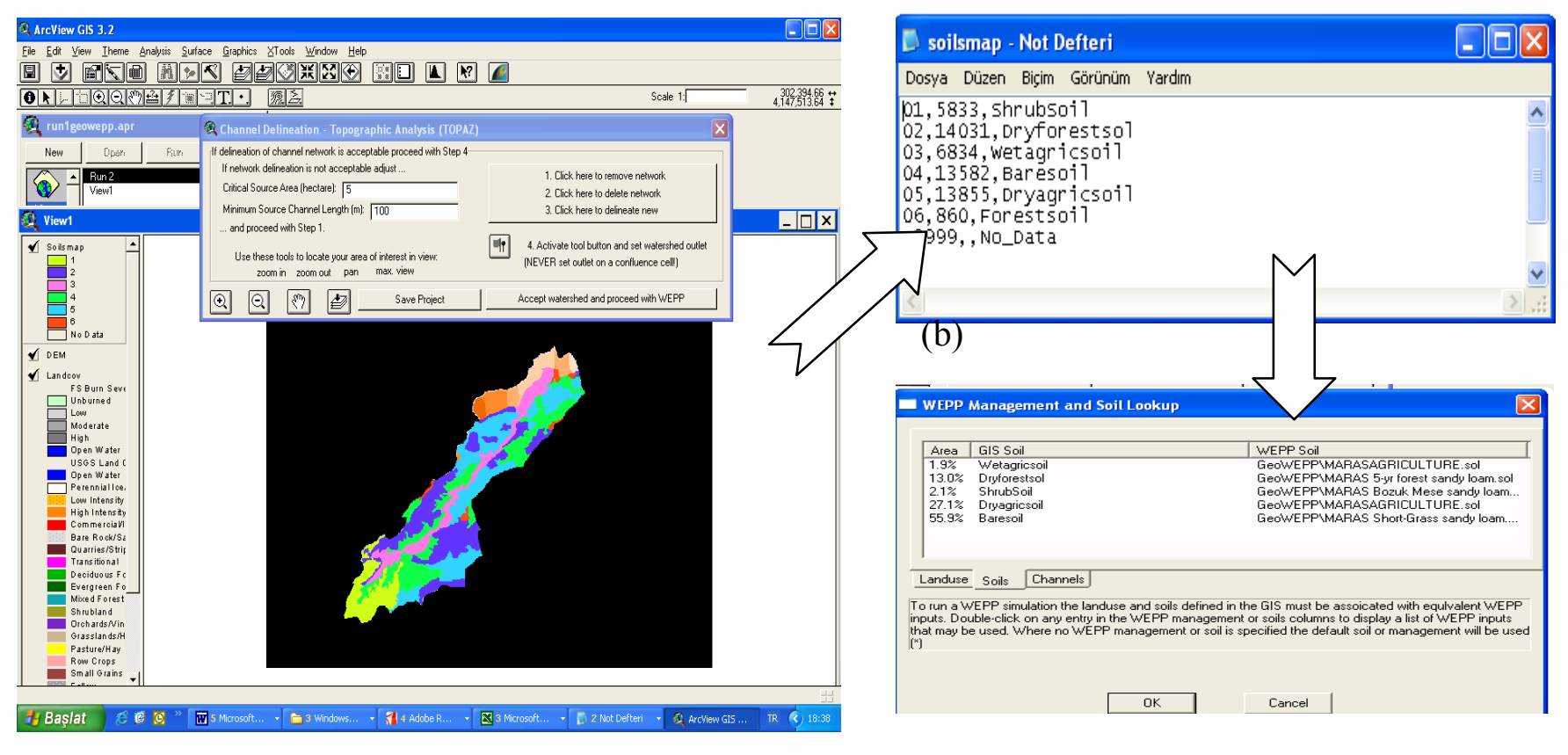

(a)

(c)

Figure 5. The interaction between soil map layer in GeoWEPP (a), soilsmap.txt (b), and WEPP/TOPAZ Translator (c). 


\section{Management File}

The amount of land cover is indicated in management file based on growth and mortality parameters. In this study, the necessary management file data (i.e. the amount of vegetation, duff, litter, and woody debris) were obtained by field measurements and then entered into the WEPP. Then, the management file was generated for different land use types (i.e. shrub, dry forest, wet agriculture, rangeland, dry agriculture, and forest) for each sub-watershed for every year of simulation. During this process, WEPP generates interrill cover data for each year using growth parameters, soil data, and climate data. To run GeoWEPP, first, the land cover layer (landcov.asc) is generated based on management file in ArcView environment (Figure 6a). Then, land cover text file (landcov.txt) (Figure $6 \mathrm{~b}$ ) is developed according to associated land use types. The land cover text file is used by GeoWEPP and WEPP/TOPAZ Translator (Figure 6c) to determine the description that corresponds with the land cover layer in GeoWEPP [7, 18]. The interaction between GeoWEPP, landcov.txt, and WEPP/TOPAZ Translator is the same as with soilsmap.txt (Figure 6).

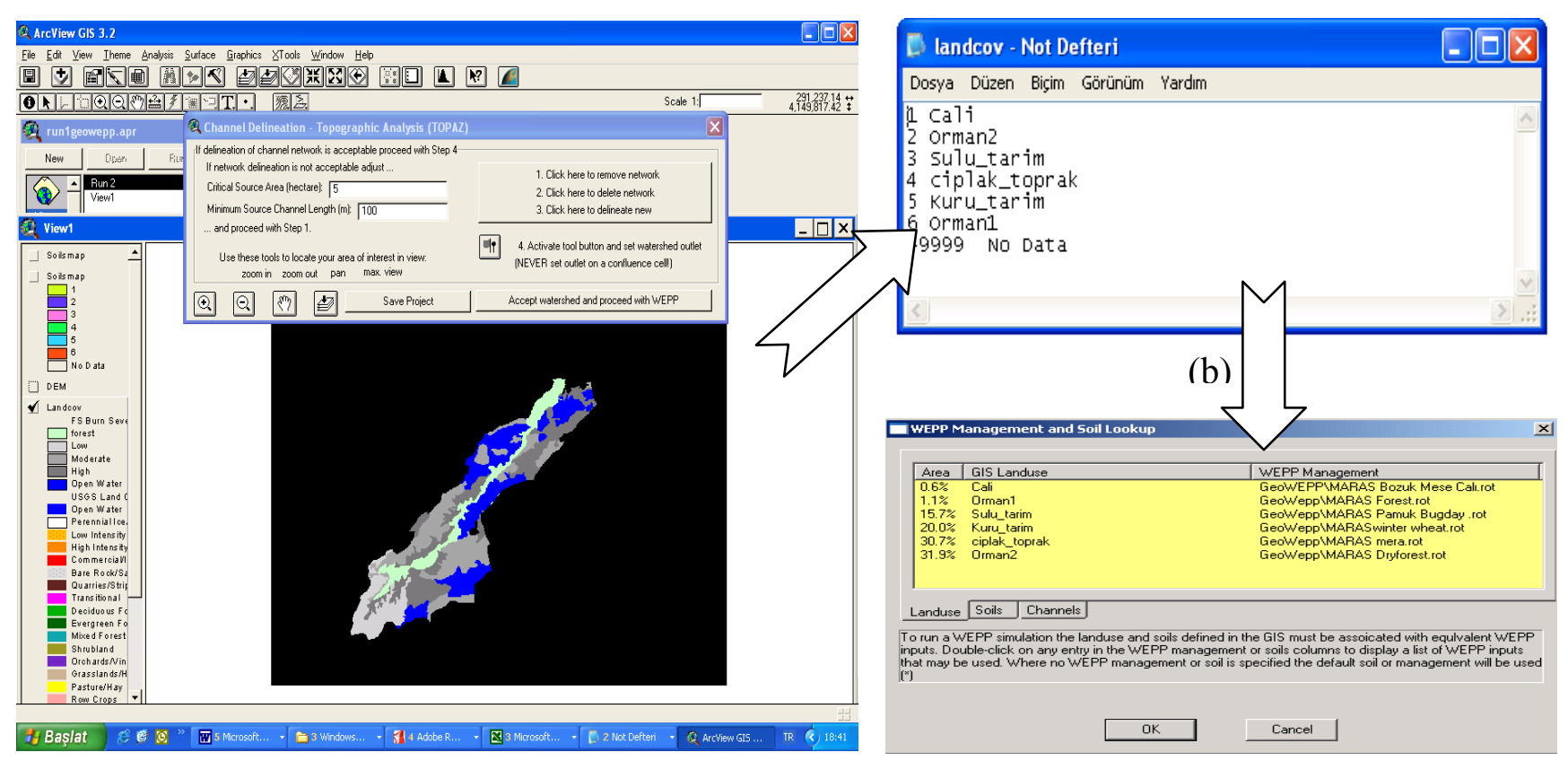

(a)

(c)

Figure 6. The interaction between land cover layer in GeoWEPP (a), landcov.txt (b), and WEPP/TOPAZ Translator (c).

\subsection{Model Application}

\subsubsection{Study Area}

Orcan Creek Watershed, located in approximately $25 \mathrm{~km}$ southeastern of Kahramanmaras, was selected as a study area because it represents the land, soil, and vegetation characteristics of the region (Figure 7). The study area is 490 ha of which 175 ha is forested land, 165 ha is rangeland, and 150 ha is agricultural land. The dominant tree species in the forest are Pinus brutia, Cedrus libani, and Quercus brantii. The average ground elevation and average-slope were $957 \mathrm{~m}$ and $34 \%$, respectively. 
The average length of watershed is $20 \mathrm{~km}$ and the width of watershed is about $2.5 \mathrm{~km}$. The annual precipitation of study area is approximately $730 \mathrm{~mm}$.

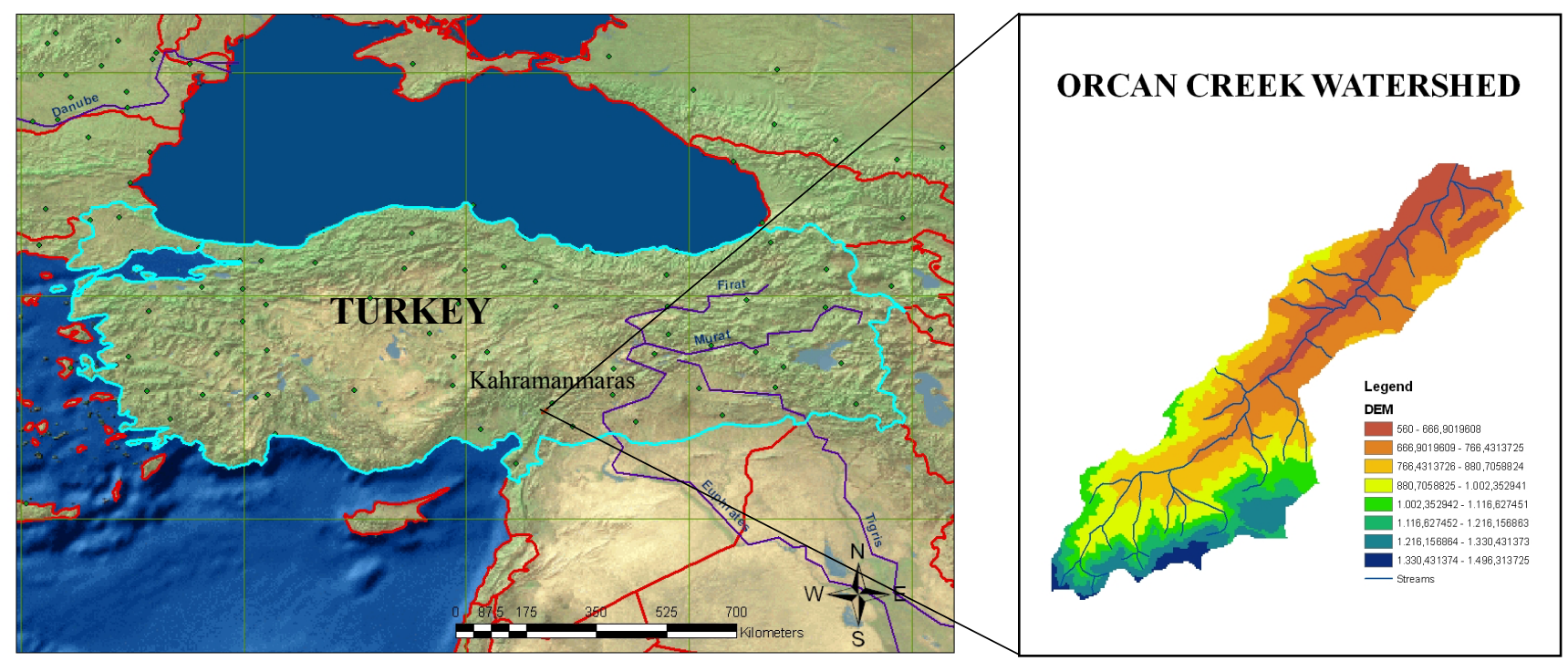

Figure 7. The location of the study area on topographic map of Turkey.

\subsubsection{Methods}

Sediment yield was measured based on sediment samples collected from the watershed outlet for one year period from April 2005 to March 2006. The samples were taken back to the laboratory to measure dry weights of the sediment for each sediment-producing event. The runoff data were obtained by using current meters and water level readings. In measuring runoff, continuous height records were taken by automatic recorders. Then, monthly sediment yield and a sum of the total sediment collected per year were calculated based on the daily sediment yield from the field data. The daily sediment yield was computed using instantaneous concentration and flow values as follows [26]:

$$
L=0.0864 C Q
$$

where, $L=$ load in $\mathrm{T} / \mathrm{d} ; C=$ instantaneous concentration, in $\mathrm{mg} / \mathrm{l}$; and $Q=$ instantaneous discharge, in $\mathrm{m}^{3} / \mathrm{s}$. The value of 0.0864 is used to convert sediment yield values from seconds to days and from milligrams to tonnes.

The yearly and monthly sediment yield and runoff outputs from GeoWEPP were generated to compare with the measured watershed sediment yield and runoff data. In GeoWEPP, the steady state sediment continuity equation was used to estimate net detachment in the hillslope as follows [27]:

$$
\frac{d G}{d x}=D_{f}+D_{i}
$$

where, $G=$ Sediment load $\left(\mathrm{kg} / \mathrm{m}^{2} / \mathrm{s}\right)$ at distance $x$ from the origin of hillslope, $x=$ Distance down slope (m), $D_{i}=$ Interrill sediment delivery rate to rill $\left(\mathrm{kg} / \mathrm{m}^{2} / \mathrm{s}\right)$, and $D_{f}=$ Rill detachment rate $\left(\mathrm{kg} / \mathrm{m}^{2} / \mathrm{s}\right) . D_{i}$ was calculated using following equation: 


$$
D_{i}=K_{i} I_{e} \sigma_{i r} S D R_{R R} F_{n o z z l e}\left(\frac{R_{s}}{w}\right)
$$

where: $K_{i}=$ Adjusted interrill erodibility $\left(\mathrm{kg} \mathrm{s} / \mathrm{m}^{4}\right), I_{e}=$ Effective rainfall intensity $(\mathrm{mm} / \mathrm{h}), \sigma_{i r}=$ Interrill runoff rate $(\mathrm{mm} / \mathrm{h}), S D R_{R R}=$ Interrill sediment delivery ratio, $F_{\text {nozzle }}=$ Adjustment factor for sprinkler irrigation nozzle impact energy variation, $R_{s}=$ Rill spacing $(\mathrm{m})$, and $w=$ Width of rill $(\mathrm{m})$. Then, $D_{f}$ was calculated using following equation:

$$
D_{f}=K_{r}\left(\tau_{f}-\tau_{c}\right)\left(1-\frac{G}{T_{c}}\right)
$$

where, $K_{r}=$ Adjusted soil erodibility parameter $(\mathrm{s} / \mathrm{m}), \tau_{f}=$ Flow shear stress $\left(\mathrm{kg} / \mathrm{m} / \mathrm{s}^{2}\right), \tau_{c}=$ Adjusted critical shear stress of the rill surface $\left(\mathrm{kg} / \mathrm{m} / \mathrm{s}^{2}\right)$, and $T_{c}=$ Sediment transport capacity of the rill flow $(\mathrm{kg} / \mathrm{m} / \mathrm{s}) . T_{c}$ was calculated as follows $[27,28]$ :

$$
T_{c}=K_{t r} q_{w} s
$$

where, $K_{t r}=$ constant parameter, $q_{w}=$ flow discharge per unit width $\left(\mathrm{m}^{2} / \mathrm{s}\right)$, and $s=$ slope $(\%)$. Finally, net deposition was computed as follows [27, 29]:

$$
\frac{d G}{d x}=\frac{\beta_{r} V_{f}}{q_{w}}\left(T_{c}-G\right)+D_{i}
$$

where, $V_{f}=$ Effective fall velocity of the sediment $(\mathrm{m} / \mathrm{s})$ and $\beta_{r}=$ Raindrop induced turbulence coefficient (0-1).

To evaluate the prediction performance of the models, the root mean squared error (RMSE) [30] was used based on specified assessment descriptors [31,32]. These descriptors include observed $(O)$ and predicted $(P)$ values, observed mean $(\hat{O})$, observed $\left(s_{o}\right)$ and predicted $\left(s_{p}\right)$ standard deviations, coefficient of determination $\left(r^{2}\right)$, slope $(b)$ and intercept $(a)$ of a least-squares regression between predicted and observed runoff and sediment, RMSE, and index of agreement $(d)$.

The RMSE is used to evaluate the performance of the model by deriving useful information about the nature of the difference between the observed and predicted values. Since the RMSE has the same units as the predicted and observed values, it can be easily interpreted [30]. The RMSE is computed based on number of paired observation $(N)$, predicted values, and observed values as follows:

$$
R M S E=\sqrt{\frac{\sum_{i=1}^{N}\left(P_{i}-O_{i}\right)^{2}}{N}}
$$

The index of agreement provides an evaluation of prediction accuracy by describing the degree to which predicted variation accurately estimates the observed variation [30]. It is computed as: 


$$
d=1-\left[\frac{\sum_{i=1}^{N}\left|P_{i}-O_{i}\right|^{2}}{\sum_{i=1}^{N}\left(\left|P_{i}-\hat{\mathrm{O}}\right|+\left|O_{i}-\hat{\mathrm{O}}\right|\right)^{2}}\right]
$$

\section{Results and Discussion}

In this study, GeoWEPP model integrating detailed spatial data with WEPP v2006.5 was used to estimate the sediment yield and runoff from Orcan Creek watershed in Kahramanmaras region. Then, the sediment yield and runoff results from the GeoWEPP model were compared with the observed monthly data collected from the sample watershed.

The GeoWEPP model generated sediment yield map which indicates the areas with tolerable yield (i.e. from light to dark green) and not tolerable yield (i.e. from light to dark red) in the study area (Figure 8). The results of t-test showed that there was no statistically significant difference $(p>0.005)$ between predicted and observed values at $p \leq 0.05$ level. The statistical comparison of predicted sediment yield and runoff against observed data revealed an $r^{2}$ of 0.94 and 0.93 , respectively (Figure 9). In a similar study, Kirnak (2002) reported comparable results where the WEPP-predicted sediment yield and runoff against observed data produced an average $r^{2}$ of 0.94 and 0.91 , respectively [33]. Thus, it can be concluded that the WEPP v2006.5 model can be used to generate acceptable predictions of sediment yield and runoff in the Orcan Creek watershed.

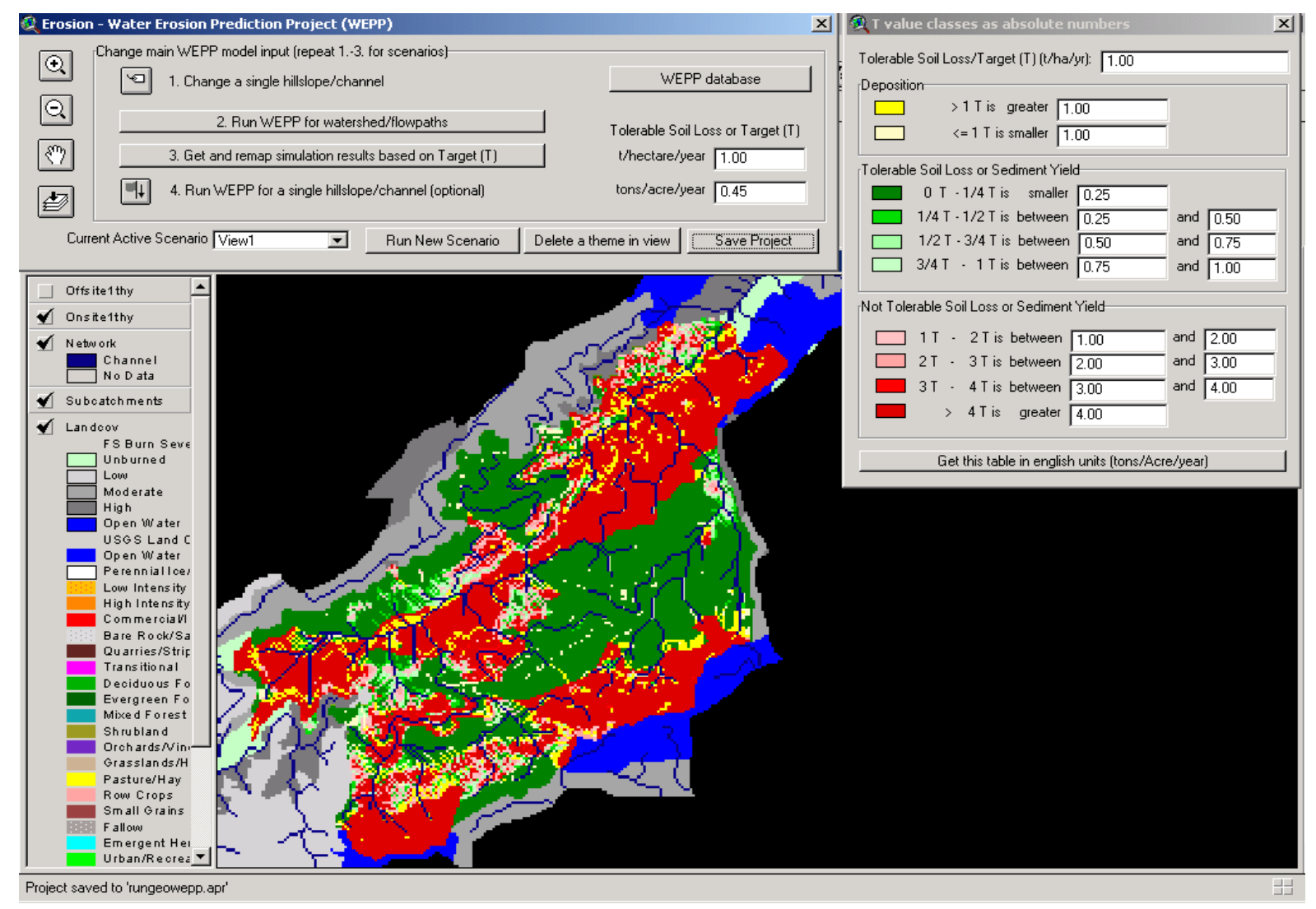

Figure 8. GeoWEPP generated annual soil loss map for Orcan Creek Watershed. 


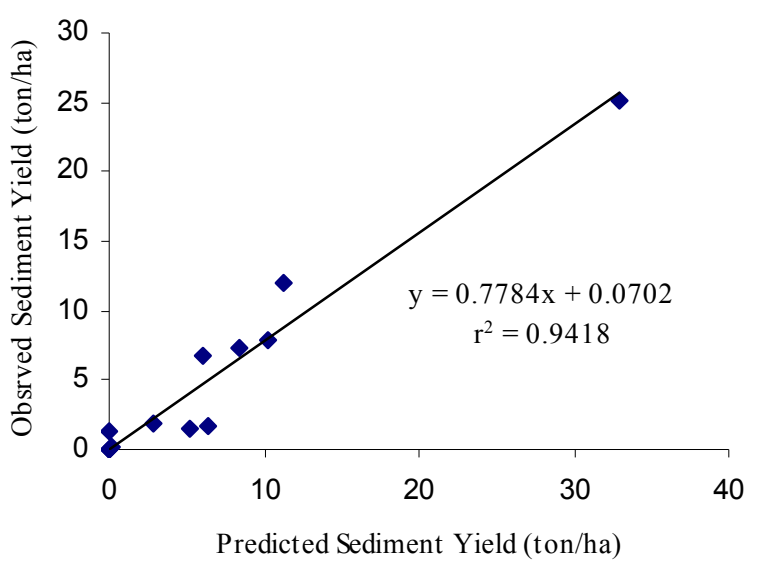

(a)

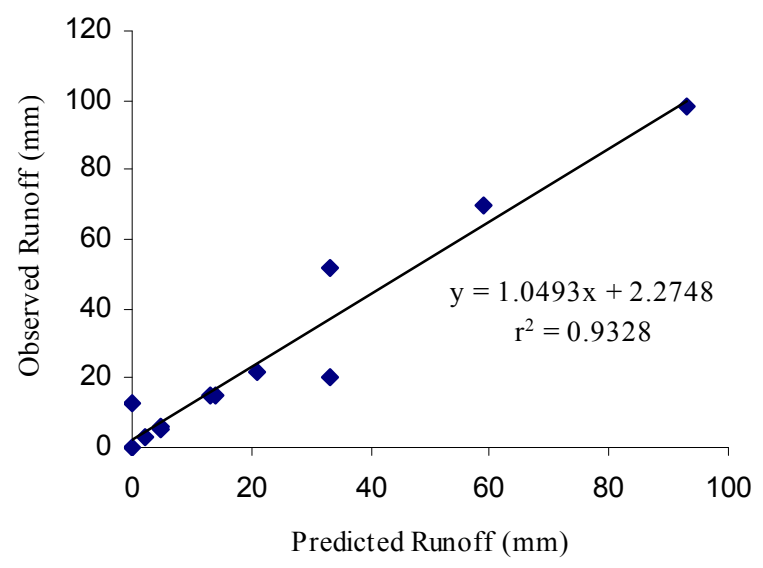

(b)

Figure 9. Regression between predicted and observed (a) sediment yield (b) runoff.

Statistical summary of predicted and observed values for sediment yield and runoff was shown in Table 1. The results indicate that the GeoWEPP model over-predicted the sediment yield by $27 \%$ and under-predicted the runoff by $13 \%$. The comparison of predicted monthly sediment yield and runoff with observed data at the watershed was indicated in Figures 10 and 11, respectively. The sediment yield and runoff prediction revealed an RMSE of 2.96 and 8.43, respectively. Besides, GeoWEPP predicted the sediment yield and runoff with the index of agreement of 0.98 and 0.97 , respectively. In a similar study, Kirnak (2002) found the RMSE and the index of agreement values of 14.75 and 11.6, and 0.64 and 0.92 for predicted sediment yield and runoff, respectively [33].

The results from the monthly predictions showed higher accuracy in sediment yields and a slight lower accuracy in runoff predictions even though the values are within the acceptable range at a 90 percent confidence level. The relatively higher actual runoff comparing with sediment yield at Orcan Creek was most likely due to subsurface lateral flow which did not contain large amounts of sediment because of filtering effect of the soil it flows through and greater soil compaction and increased erosion due to higher clay content in the soil [16].

Table 1. Statistical summary of monthly predicted and observed values for sediment yield and runoff.

\begin{tabular}{lrrrr}
\hline \multirow{2}{*}{$\begin{array}{l}\text { Statistical } \\
\text { Parameters }\end{array}$} & \multicolumn{2}{c}{ Sediment (ton/ha) } & \multicolumn{2}{c}{ Runoff (mm) } \\
\cline { 2 - 5 } Mean & Predicted & Observed & Predicted & Observed \\
Std Deviation & 6.95 & 5.48 & 23.17 & 26.58 \\
N & 9.13 & 7.32 & 28.17 & 30.60 \\
Intercept & 12.00 & 12.00 & 12.00 & 12.00 \\
Slope & \multicolumn{2}{c}{0.07} & \multicolumn{2}{c}{2.28} \\
$r^{2}$ & \multicolumn{2}{c}{0.78} & \multicolumn{2}{c}{1.05} \\
RMSE & \multicolumn{2}{c}{0.94} & \multicolumn{2}{c}{0.93} \\
Index of & \multicolumn{2}{c}{8.43} \\
Agreement & \multicolumn{2}{c}{0.96} & \multicolumn{2}{c}{0.97} \\
\hline
\end{tabular}




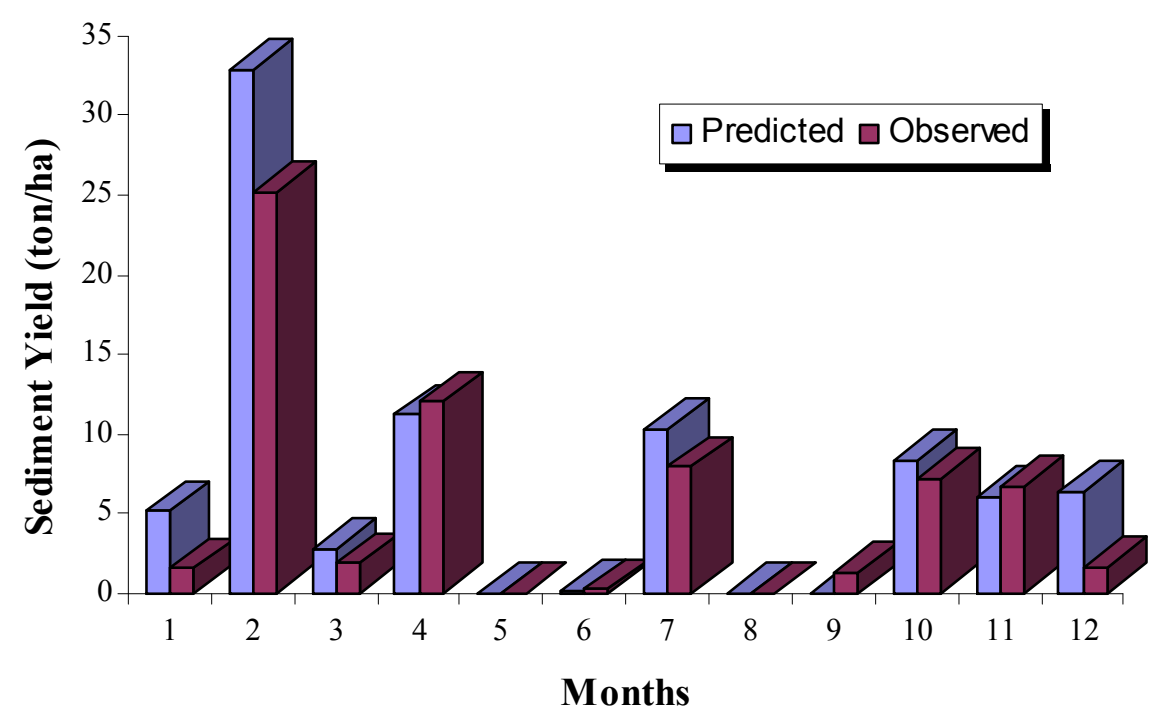

Figure 10. Comparison of predicted and observed sediment yield.

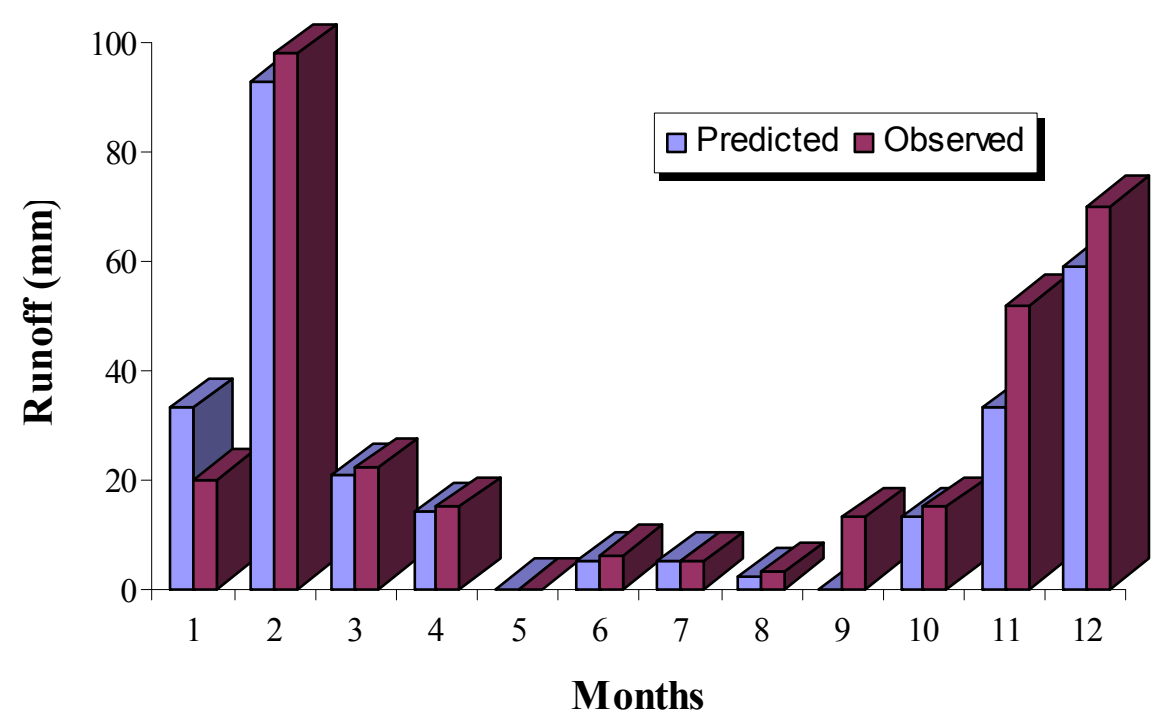

Figure 11. Comparison of predicted and observed runoff.

\section{Conclusion}

The overall results indicated that the GeoWEPP model can assist watershed-related management institutions to quickly and accurately generate acceptable predictions of sediment yield and runoff outputs in textual or graphical format based on digital data base of the watershed. Besides, the model provides the managers with the information of areas with high sediment delivery potential. Therefore, watershed managers can locate the problematic areas in a watershed and implement necessary precaution measures to minimize or prevent sediment yield and runoff. It is highly anticipated that interests in using GeoWEPP will be increasing in Turkey as well as all over the world, as more people utilize advanced GIS techniques and computer-based methods in their sediment yield and runoff prediction studies. 


\section{Acknowledgements}

The research described here was carried out during a visit to the Rocky Mountain Research Station at Moscow, Idaho, USA in 2006. I would like to thank Dr. William J. Elliot for his interest, time, encouragement, and valuable helps during this research. Also thanks to Dr. Pete Robichaud, David E. Hall, Martin Minkowski, Dr. Joan Wu, and Shuhui Dun for their helps on model input files studies. Financial support was provided by The Scientific \& Technological Research Council of Turkey for this research.

\section{References}

1. GDREC, General Directorate of Reforestation and Erosion Control, http://www.agm.gov.tr, visited on January 8th, 2008.

2. Akay, A.E.; Erdas, O.; Reis,M.; Yuksel, A. Estimating sediment yield from a forest road network by using a sediment prediction model and GIS techniques. Building and Environment 2008, 43(5), 687-695.

3. Akay, A.E.; Sessions, J. Applying the Decision Support System, TRACER, to Forest Road Design. Western Journal of Applied Forestry 2005, 20(3), 184-191.

4. Yuksel, A.; Akay, A.E.; Elliot, W.J. Using WEPP: Road Model in Estimating Sediment Yield from the Road Network in KSU Baskonus Research and Application Forest in Kahramanmaras, Turkey. International Mountain Logging and 13th Pacific Northwest Skyline Symposium; Oregon State University, Corvallis, Oregon, USA, 1-6 April 2007.

5. Covert, A. Accuracy Assessment of WEPP-Based Erosion Models On Three Small, Harvested And Burned Forest Watersheds. MSc Thesis, Natural Resource College of University of Idaho, USA, 2003

6. Renard, K.; Foster, G.; Weesies, G.; McCool, D.; Yoder, D. Predicting Soil Erosion by Water: A Guide to Conservation Planning with the Revised Universal Soil Loss Equation (RUSLE), USDA Agr. Handbook, 1997, No 703.

7. Yuksel, A.; Akay, A.E.; Reis, M.; Gundogan.;R. Using The WEPP Model To Predict Sediment Yield In A Sample Watershed In Kahramanmaras Region. International Congress River Basin Management 2007, 2, 11-22.

8. Beasley, D.B.; Huggins, L.F.; Monke, E.J. ANSWERS: A model for watershed planning. Trans. of the ASAE 1980, 23(4), 938-944.

9. Bouraoui, F.; Dillaha, T.A. ANSWERS-2000: Runoff and sediment transport model. Journal of Environmental Engineering 1996, 122(6), 493-502.

10. Wischmeier, W.H. Use and misuse of the universal soil loss equation. Journal of Soil and Water Conservation 1976, 31(1), 5-9.

11. CORINE. Soil Erosion Risk and Important Land Resources in the Southeastern Regions of the European Community. 1992, EUR 13233, Luxembourg, BELGIUM.

12. Bayramin, D.; O, Baksan.; O, Parlak M. Soil Erosion Risk Assessment with ICONA Model; Case Study: Beypazarı Area. Turkish Journal of Agriculture and Forestry 2003, 23, 105-116.

13. Flanagan, D.C.; S.J. Livingston. WEPP user summary: USDA-Water Erosion Prediction Project (WEPP). USDA-ARS National Soil Erosion Research Laboratory, 1995 NSERL Report No. 11. 
14. Flanagan, D.C.; M.A. Nearing. USDA-ARS National Soil Erosion Research Laboratory, 1995 NSERL Report No. 10.

15. Elliot, W.J.; D.E. Hall.; D.L. Scheele. FS WEPP: Forest Service Interfaces for the Water Erosion Prediction Project Computer Model. 1999a, Available at http://forest.moscowfsl.wsu.edu/fswepp/docs/fsweppdoc.html., Accessed 9 December 2007.

16. Wu, J.Q.; A.C. Xu.; W.J. Elliot.. Adapting WEPP (Water Erosion Prediction Project) for forest watershed erosion modeling: ASAE Paper No. 002069. St. Joseph, MI: American Society of Agricultural Engineers 2000, 9 p.

17. Renschler, C. Geo-spatial Interface for the Water Erosion Prediction Project GeoWEPP ArcX, 2002, http://www.geog.buffalo.edu/ rensch/geowepp/GeoWEPP\%20Manual_files/frame.htm Accessed 15 December 2007.

18. Minkowski, M. Advanced GeoWEPP Tools. Accessed 15 December 2007. (http://www.geog.buffalo.edu/ rensch/geowepp/documents)

19. Garbrecht, J. and L.W. Martz., TOPAZ: Topographic Parameterization Software. 1997, Available at: http://grl.ars.usda.gov/topaz/TOPAZ1.HTM. Accessed 10 December 2007.

20. USDA Agricultural Research Service and USDA Forest Service, CLIGEN Weather Generator, Expand and Improved. 2003, Available at: http://horizon.nserl.purdue.edu/Cligen, Accessed 12 December 2007.

21. Elliot, W.J.; D.E. Hall.; D.L. Scheele. Disturbed WEPP: WEPP interface for Disturbed Forest and Range Runoff, Erosion and Sediment Delivery. 2002, Available at: http://fsweb.moscow.rmrs.fs.fed.us/fswepp/docs/distweppdoc.html., Accessed 7 December 2007.

22. Daly, C.; R.P. Neilson.; D.L. Phillips. A statistical-topographic model for mapping climatological precipitation over mountainous terrain. Journal of Applied Meteorology 1994, $33(2), 140-158$.

23. Elliot, W.J.; D.E. Hall. Rock:Clime Beta CD Version Rocky Mountain Research Station Stochastic Weather Generator Technical Documentation. 2000, Available at: http://forest.moscowfsl.wsu.edu/fswepp/docs/0007RockClimCD.html, Accessed 5 December 2007.

24. Alberts, E.E.; M.A. Nearing.; M.A. Weltz.; L.M. Risse.; F.B. Pierson.; J.R. Simanton. Soil component. USDA-Water Erosion Prediction Project: Hillslope Profile and Watershed Model Documentation 1995, 7.1-7.47. NSERL Report No. 10.

25. Robichaud, P.R.. Spatially- varied erosion potential from harvested hillslopes after prescribed fire in the interior Northwest. Ph.D. diss. Moscow, ID: University of Idaho, Department of Agricultural Engineering 1996, 219 p.

26. EIEI. Suspended Sediment Data and Sediment Transport Amount for Surface Waters in Turkey. General Directorate of Electrical Power Resources Survey and Development Administration, Spec. Pub. 2000, 20/17, Ankara.

27. Foster GR, Flanagan DC, Nearing MA, Lane LJ, Risse LM and Finkner SC () Chapter 11: Hillslope Erosion Component In USDA Water Erosion Prediction Project : Hillslope Profile and Watershed Model Documentation 1995, NSERL Report No. 10.

28. Huang C.H.; Bradford JM. Analysis of Slope and Runoff Factors Based on the WEPP Erosion Model Soil Science Society of America Journal 1993, 57, 1176-118329. 
29. Foster GR and Meyer LD. A closed-form soil erosion equation for upland areas. In Sedimentation Ed, Shen, H. W. Department of Civil Engineering, Colorado State University, Fort Collins 30.

30. Willmott, C.J. On the validation of models. Physical Geography 1981, 2(2), 184-194.

31. Elliot, W.J.; A.V. Elliot.; W. Qiong.; J.M. Laflen. Validation of the WEPP model with rill erosion plot data. ASAE Paper No. 91-2557. St. Joseph, MI: American Society of Agricultural Engineers 1991, 11 p.

32. Povilaitis, A.; P. Robichaud.; A. Dumbrauskas.; R.Tumas.; J. Ruseckas. Erosion prediction in the republic of Lithuania with the WEPP model. In Proc. Water Quality Modelin 1995, 333-340. Orlando, FL. St Joseph, MI: American Society of Agricultural Engineers.

33. Kirnak, H. Comparison of Erosion and Runoff Predicted by WEPP and AGNPS Models Using a Geographic Information System, Turkish Journal of Agriculture and Forestry 2002, 26, 261-268.

(C) 2008 by MDPI (http://www.mdpi.org). Reproduction is permitted for noncommercial purposes. 